\title{
Correlation of changes in the employment costs and average task load with rates of accidents attributed to human error
}

\author{
Author(s) \\ Karanikas, Nektarios \\ DOI
}

10.1027/2192-0923/a000083

Publication date

2015

Document Version

Submitted manuscript

\section{Published in}

Aviation Psychology and Applied Human Factors

\section{Link to publication}

\section{Citation for published version (APA):}

Karanikas, N. (2015). Correlation of changes in the employment costs and average task load with rates of accidents attributed to human error. Aviation Psychology and Applied Human Factors, 5(2), 104-113. https://doi.org/10.1027/2192-0923/a000083

If you believe that digital publication of certain material infringes any of your rights or (privacy) interests,

please let the Library know, stating your reasons. In case of a legitimate complaint, the Library will make the material inaccessible and/or remove it from the website. Please contact the library:

https://www.amsterdamuas.com/library/contact/questions, or send a letter to: University Library (Library of the University of Amsterdam and Amsterdam University of Applied Sciences), Secretariat, Singel 425, 1012 WP Amsterdam, The Netherlands. You will be contacted as soon as possible.

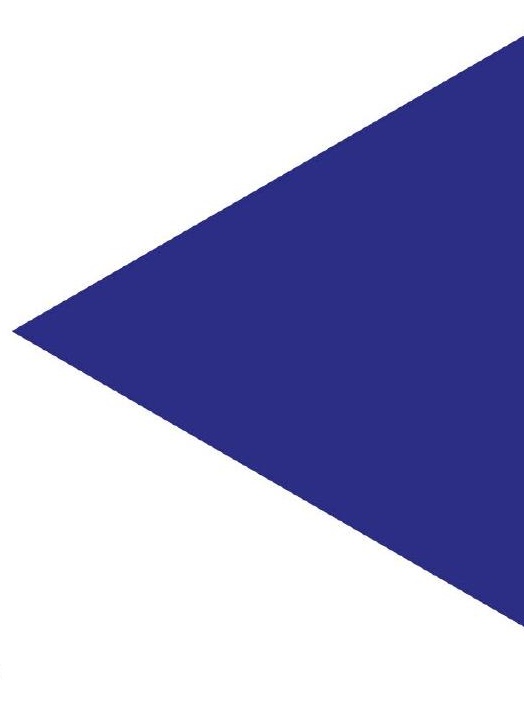




\title{
Pre-print version. Post-print version: DOI: 10.1027/2192-0923/a000083
}

Correlation of Changes in the Employment Costs and Average Task Load with Rates

\author{
of Accidents Attributed to Human Error
}

Research Paper

Author: Nektarios Karanikas

Affiliation: Amsterdam University of Applied Sciences / Aviation Academy

Address: Weesperzijde 190, 1097 DZ, Amsterdam, Netherlands

Email: n.karanikas@hva.nl,nektkar@gmail.com

Tel.: +31621156287

\section{ABSTRACT}

Market competition and global financial uncertainty have been the principal drivers that impel aviation companies to proceed to budget cuts, including decreases in salary and work force levels, in order to ensure viability and sustainability. Under the concepts of Maslow and Herzberg's motivation theories, the current paper unfolds the influence of employment cost fluctuations on an aviation organization's accidents attributed to human error. This study exploited financial and accident data over a period of 13 years, and explored if rates of accidents attributed to human errors of flight, maintenance and ramp crews, correlate with the average employment expenditures $(\mathrm{N}=13)$. In addition, the study took into account the relationship between average task load (ratio of flying hours per employee) and accident rates related to human error since task load, as part of total workload, is a constraint of modern complex systems. The results revealed strong correlations amongst accident rates linked to human error with the average employment costs and task load. The use of more specific data per aviation organizational department and professional group may further validate the results of this study. Organizations that seek to explore the 
association between human error and employment budget and task load might appropriately adapt the approach proposed.

Keywords: motivation, payment, accident rates, human error, task load, aviation

\section{INTRODUCTION}

\subsection{Classic Motivation Theories}

Psychologists and safety professionals have discussed deeply and widely human error and have addressed various parameters affecting human performance, amongst which motivation plays a paramount role (e.g., Stranks, 2006; Stranks, 2008). Two of the most cited motivation theories are Maslow's hierarchy of needs (Maslow, 1954) and Herzberg's satisfaction and dissatisfaction factors (Herzberg, Mausner, \& Snyderman, 1959). The former suggested that human motivation depends on the fulfilment of needs, which are subject to a hierarchical order. This specific theory remains prevalent, although it has received criticism regarding its ranking of needs (e.g., Diener \& Tay, 2011; Huizinga, 1970) and promotion of "ego" (Yankelovich, 1981).

According to Maslow's theory (1954), as cited by various authors (e.g., Griffin, 1996; Pardee, 1990), humans cannot obtain a self-actualization state if they have not fulfilled the lower levels of needs, as follows:

- The fulfilment of physiological needs (e.g., shelter, food, suitable living environment) forms the critical factor that will determine the transition to the next level.

- Since individuals satisfy physiological needs, they move to the step of guarding the environment against external and internal threats and hazards, and become 
aware of factors that may impede health, employment conditions and etcetera; this is the safety and security stage.

- Social needs such as belonging and love follow the ones of safety and security and constitute predecessors of the esteem needs.

- Esteem needs represent the human desire to achieve a high level of competency and mastery in specific fields.

- The ultimate goal is the self-actualization level at which people continuously try to increase their potential through a spectrum of initiatives (e.g., quest for deeper and wider knowledge, dissemination of humanitarian values, and self-fulfilment).

Herzberg et al. (1959), distinguished between the hygiene and motivational factors, without considering them opposites. Under their theory, the motivational factors (e.g. job nature, recognition, responsibility, achievement and growth) can provoke either satisfaction or dissatisfaction. The hygiene factors (e.g., organizational policy, supervision, working conditions, workplace relations, salary, job security, status and personal life) cause satisfaction when they are present or dissatisfaction when they are absent.

\subsection{Job Satisfaction and Human Error}

Both motivation theories cited above include job payment and working conditions as crucial factors related to satisfaction. Maslow (1954) rather approached human needs sharper than Herzberg et al. (1959) did. The hierarchy of needs suggests that the complete satisfaction of living conditions determine the transition to the next level (i.e. safety and security); hence, when humans do not fulfil their basic needs, they might not consider safety as of high priority, consequently, work related human errors might increase. However, whatever individuals consider satisfactory concerning their physiological needs comprises a topic of extensive debate since the 
perception of satisfaction varies across societies, nations, professional groups, etcetera. Herzberg did not consider salary and working conditions as directly related to motivation, but suggested that decreased payment and inappropriate working conditions (e.g., noise, peer-pressure and task load) are dissatisfaction factors, thus, preconditions of human error.

International Civil Aviation Organization (ICAO, Safety Management Manual, 2013) suggested that safety management must, amongst several factors, consider the policies related to budget constraints since the latter are an error provoking factor; payment levels decrease and task load escalation are directly connected to such budget cuts. Moreover, ICAO (2004) described the interaction of the organizations with the economic and political context, including factors such as national wealth, tax base, per capita income, population size and density, economic and political stability, legislation, and education.

Giamalis and Moschoutas (2013) explored the data of an aviation organization and compared the accident rates between two periods (i.e. 2007-2009 and 2010-2012) in order to assess the influence of the Greek financial crisis on operational safety. The authors concluded that there was an $8.5 \%$ increase in the incidents and a $10 \%$ escalation of accidents caused by human error; they further decomposed human errors into crew errors $(4.8 \%$ increase) and maintenance staff errors (27\% increase). Moreover, the analysis of data collected during the same study showed an overall deterioration of the working conditions during the financial crisis.

Beyond the aviation sector, Eksler, Hollo, and Zukowska (2010) in their study regarding central European countries concluded that the socio-economic climate affected the rates of road accidents attributed to human error, but the wide range of 
contributing factors did not allow the development of a prediction model; the authors found that economic improvement was correlated with decreased road fatality trends.

\subsection{Payment and Job Satisfaction}

Several authors have explored the relationship between payment levels and job satisfaction in various domains. However, the results of the relevant studies have been contradictory rather than supplemental. Broman, Edmund, Milner, Pentsil, and Young (2014) suggested that increases in salary were directly associated with decreases in satisfaction. Furthermore, Judge, Piccolo, Podsakoff, Rich, and Shaw (2010) in their meta-analysis of data from 92 studies, correlated pay level with job satisfaction and concluded that the former is only marginally correlated with the latter. At a more reserved view, Allsop, Eksler, Jost, and Popolizio (2009, p. 14) in their work on road safety quoted an interviewee's statement: "It is difficult to evaluate the exact influence of the economic situation on road safety be it in a time of recession or economic boom".

Contradictory to the literature cited above, Beutell and Wittig-Berman (1999) and Igalens and Roussel (1998) claimed that increased salary is positively related to job satisfaction. The work of Gerhart, Minette, and Rynes (2004) revealed pay as an important motivator; however, as the authors recognised, organizations should always consider the wide spectrum of motivators determining satisfaction and human performance.

Further literature cited by Gerhart et al. (2004) referred to the relation between payment as a motivational factor, and productivity as an indicator of workforce satisfaction. Denny, Feren, Locke, McCaleb, and Shaw (1980) found that individual payment incentives caused a $30 \%$ increase in production. A similar study by Judiesch 
(1994) calculated that pay incentives increased productivity up to 44\%. Guzzo, Jette, and Katzell (1985) concluded that payment level had the greatest effect on productivity and more specifically, such effects were four times more important than the ones attributed to other intervention types. Luthans and Stajkovic (1997) computed similar effects of pay incentives, feedback and social rewards on productivity. Although Gupta, Jenkins, Mitra, and Shaw (1998) indicated a positive correlation between payment and productivity, such association was not established between payment and product quality.

\subsection{Scope of the Research}

Rasmussen (1997) argued that economy, workload and safety constitute the principal constraints of complex systems. As the complexity of the modern world increases, the nature of human error changes and employees become more vulnerable to the numerous interconnections and interrelations of system components (e.g., Dekker, 2014; Hollnagel, 2014). However, in the light of such complexity, there has not been sufficient research on the relationship between wage fluctuations and human error rates in conjunction with task load variances, from the perspective of basic motivational theories. As Brubaker and Probst (2001) noted, the majority of the literature addresses other factors affecting safety, such as ergonomic conditions and organizational and individual characteristics.

Therefore, taking into account suggestions from the literature regarding the relationship of payment levels and working conditions with motivation and job satisfaction, the current study exploited data from an aviation organization and explored the association between rates of accidents attributed to human error and

fluctuations of employment expenditures and task load. Quantification of the 
relationship of such accident rates with employment costs and average task load might guide organizations and authorities towards targeted interventions.

It is clarified that task load is defined as the time allotted to perform a task divided by this amount of time (Gawron, 2008). As Stone, Gulick, \& Gabriel (1984) and Mavor, McGee, \& Wickens (1997) articulated, task load does not count equally for the workload because the former does not consider cognitive activities, variations of individual factors (e.g., physiological state, skills, experience and adaptive behaviour) and system performance variability. However, albeit workload and task load are not identical terms, the latter is seen as contributor to the former and comprises part of the working conditions (e.g., Hilburn \& Jorna, 1999).

\section{METHODOLOGY}

\subsection{Sample}

The present study was conducted in an aviation organization that operates flights, offers maintenance of aircraft and ground equipment, and has a complete range of functions to support its services (e.g., logistics, administration, financing, training, engineering, human resource management). The research exploited flight activity, financial and accident records for a period of 13 years, from 2000 to 2012, and employed the criteria explained below.

The financial data of Table 1 were derived from annual reports that are published internally and remain confidential; the employment budget covers wages, salaries, compensations and allowance expenditures. Employment costs' breakdown analysis was not available; hence, it was not possible to explore variances within and between groups, such as job role, gender, and department. The Human Resources Department provided data of the entire employees' population for each year of study 
(Table 1); the average per capita cost represents the ratio of employment budget per employee.

\begin{tabular}{|c|c|c|c|}
\hline YEAR & $\begin{array}{c}\text { EMPLOYMENT } \\
\text { BUDGET }(€)\end{array}$ & $\begin{array}{c}\text { TOTAL EMPLOYEES } \\
\text { POPULATION }\end{array}$ & PER CAPITA \\
\hline 2000 & $418,002,655$ & 16,964 & $24,640.57$ \\
\hline 2001 & $448,909,573$ & 17,430 & $25,755.00$ \\
\hline 2002 & $488,794,284$ & 18,155 & $26,923.40$ \\
\hline 2003 & $546,989,955$ & 19,460 & $28,108.43$ \\
\hline 2004 & $598,033,963$ & 19,634 & $30,459.10$ \\
\hline 2005 & $641,164,054$ & 21,272 & $30,141.22$ \\
\hline 2006 & $685,422,879$ & 21,224 & $32,294.71$ \\
\hline 2007 & $687,524,234$ & 21,033 & $32,687.88$ \\
\hline 2008 & $750,901,226$ & 20,329 & $36,937.44$ \\
\hline 2009 & $750,849,890$ & 20,116 & $37,326.00$ \\
\hline 2010 & $627,077,178$ & 20,251 & $30,965.25$ \\
\hline 2011 & $643,284,000$ & 19,811 & $32,471.05$ \\
\hline 2012 & $590,900,000$ & 16,964 & $30,081.96$ \\
\hline
\end{tabular}

\section{Table 1: Financial and Manpower Data}

The annual safety bulletins published by the organization under study are also confidential, distributed only internally, and comprised the source of accident data for this research. The organization does not release data for incidents, and classifies as an accident any safety event incurring costs over $€ 2,000$ and/or minor injuries resulting to work role change or job limitations. Consistent accident data for the specific period were available only for accidents that occurred during aircraft operation and movement (i.e. pushback, taxiing, take-off, flight, landing, and parking) or aircraft maintenance and ground handling at the flight line or the maintenance hangar. Therefore, the study considered only accidents that regarded activities on aircraft and 
explored influence of variables on human error rates of pilots and maintenance personnel directly involved in such activities.

The researcher contemplated the arguments of modern safety thinkers, who claim a non-linear relation between accident cause and effect (e.g., Dekker, 2014; Leveson, 2004; Hollnagel, 2014). Furthermore, Karanikas (2015) discussed that organizations assign accident severity categories without counting for the extent endusers intervened into the accident progress. Under these concepts, the current research considered all human error related accidents, regardless of their classification as major or minor.

The specific organization classifies accident factors in the categories listed below (in alphabetical ascending order):

- Bird strikes.

- Flight crew acts.

- Domestic Objects Debris (DOD).

- Foreign Objects Debris (FOD), excluding Bird Strikes.

- Maintenance personnel acts.

- Material failures, excluding DODs.

- No cause identified.

- Other factors (e.g., weather).

- Outsource - depot maintenance acts.

- Supervision of flight crew and maintenance staff activities.

The annual safety bulletins include also the flight activity per year. Thus, in order to calculate the accident rates per factor for each calendar year, the number of accidents per cause was divided by the total flying hours. Afterwards, each 
fraction was multiplied by 100,000 in order to provide a convenient illustration of rates (Table 2).

Under the scope of this research, the accident factor rates considered are the ones directly linked to human error: Supervision (column SUPERVISION ERROR RATE), Maintenance Personnel Acts (column MAINTENANCE STAFF ERROR RATE), and Flight Crew Acts (column CREW ERROR RATE). The research included all accidents attributed to human error, either as the only contributing factor or in combination with other causes (e.g., adverse weather conditions or unclear documentation).

Furthermore, two columns were added in Table 2, as follows:

- END-USER ERROR RATE, which combines accident rates attributed solely or conjointly to maintenance staff and flight crew errors, and accidents caused by FOD. It is clarified that the organization attributes the accidents due to FOD to human error, even if the accident investigators did not identify specific employees who actively contributed to an FOD accident; for instance, damage due to loose parts from equipment and aircraft are attributed to human error, such as inattention, complacency and slips. Hence, the rates of accidents attributed to "end-user error" include all cases of human errors that contributed to accidents during flight, maintenance and ground handling activities, regardless job role.

- TOTAL HUMAN ERROR RATE, which served as indicator of accidents attributed to human error regardless the function of the persons involved (operator or/and supervisor). Under this concept, the specific rate was calculated as a combination of SUPERVISION and END-USER error rates. 
It is noted that the accidents attributed to any combination of flight crew, maintenance personnel and supervisory errors, as well FOD events, were counted once in the calculation of END-USER and TOTAL HUMAN ERROR cases explained above.

\begin{tabular}{|c|c|c|c|c|c|c|c|c|c|c|}
\hline \multirow[t]{2}{*}{ YEAR } & \multicolumn{2}{|c|}{$\begin{array}{l}\text { SUPERVISION } \\
\text { ERROR }\end{array}$} & \multicolumn{2}{|c|}{$\begin{array}{l}\text { MAINTENANCE } \\
\text { STAFF ERROR }\end{array}$} & \multicolumn{2}{|c|}{$\begin{array}{l}\text { FLIGHT CREW } \\
\text { ERROR }\end{array}$} & \multicolumn{2}{|c|}{$\begin{array}{l}\text { END-USER } \\
\text { ERROR }\end{array}$} & \multicolumn{2}{|c|}{$\begin{array}{l}\text { TOTAL } \\
\text { ERROR }\end{array}$} \\
\hline & ACC* & RATE & ACC* & RATE & ACC* & RATE & ACC* & RATE & ACC* & RATE \\
\hline 2000 & 21 & 20.55 & 26 & 25.44 & 25 & 24.46 & 33 & 32.29 & 55 & 53.81 \\
\hline 2001 & 29 & 28.69 & 14 & 13.85 & 22 & 21.76 & 37 & 36.60 & 45 & 44.52 \\
\hline 2002 & 9 & 8.60 & 13 & 12.42 & 14 & 13.38 & 18 & 17.20 & 30 & 28.67 \\
\hline 2003 & 20 & 18.34 & 15 & 13.75 & 25 & 22.92 & 34 & 31.18 & 47 & 43.10 \\
\hline 2004 & 19 & 16.53 & 14 & 12.18 & 21 & 18.27 & 34 & 29.57 & 46 & 40.01 \\
\hline 2005 & 24 & 22.38 & 17 & 15.85 & 17 & 15.85 & 34 & 31.70 & 45 & 41.96 \\
\hline 2006 & 17 & 17.12 & 9 & 9.06 & 21 & 21.15 & 33 & 33.23 & 39 & 39.27 \\
\hline 2007 & 17 & 16.88 & 5 & 4.96 & 12 & 11.91 & 20 & 19.85 & 22 & 21.84 \\
\hline 2008 & 11 & 10.81 & 8 & 7.86 & 10 & 9.83 & 14 & 13.76 & 20 & 19.66 \\
\hline 2009 & 16 & 15.71 & 3 & 2.95 & 11 & 10.80 & 15 & 14.73 & 20 & 19.64 \\
\hline 2010 & 14 & 15.78 & 3 & 3.38 & 10 & 11.27 & 15 & 16.90 & 17 & 19.16 \\
\hline 2011 & 8 & 10.19 & 5 & 6.37 & 4 & 5.09 & 10 & 12.73 & 18 & 22.92 \\
\hline 2012 & 3 & 4.61 & 8 & 12.28 & 8 & 12.28 & 8 & 12.28 & 19 & 29.17 \\
\hline
\end{tabular}

Table 2: Accident Factors' Rates per 100,000 flying hours

Table 3 presents examples of accidents attributed to human error and included in Table 2 data.

\begin{tabular}{|l|l|l|l|}
\hline STAFF INVOLVED & ACTIVITY & ERROR & OUTCOME \\
\hline Flight Crew & Flight & $\begin{array}{l}\text { Failure to complete } \\
\text { landing checklist }\end{array}$ & $\begin{array}{l}\text { Wheels-up } \\
\text { (belly) landing }\end{array}$ \\
\cline { 2 - 4 } & Ground Movement & $\begin{array}{l}\text { Choosing the wrong } \\
\text { taxiway }\end{array}$ & $\begin{array}{l}\text { Ground collision } \\
\text { with another } \\
\text { aircraft }\end{array}$ \\
\hline Maintenance Staff & Flight Line Service & $\begin{array}{l}\text { Access panel not fully } \\
\text { secured }\end{array}$ & $\begin{array}{l}\text { Panel detached } \\
\text { during take-off }\end{array}$ \\
\cline { 2 - 4 } & Maintenance in Hangar & Incomplete hydraulic & Loss of hydraulic \\
\hline
\end{tabular}




\begin{tabular}{|c|c|c|c|}
\hline STAFF INVOLVED & ACTIVITY & ERROR & OUTCOME \\
\hline & & pump installation & $\begin{array}{l}\text { pressure in No } 1 \\
\text { system during } \\
\text { flight }\end{array}$ \\
\hline \multirow{2}{*}{$\begin{array}{l}\text { End-user (Flight Crew } \\
\text { and Maintenance Staff } \\
\text { Acts combined) }\end{array}$} & Maintenance in Hangar & $\begin{array}{l}\text { Loose object left inside } \\
\text { engine }\end{array}$ & \multirow{2}{*}{$\begin{array}{l}\text { No } 1 \text { engine } \\
\text { failure and abort } \\
\text { of take-off, } \\
\text { leading to } \\
\text { runway } \\
\text { excursion }\end{array}$} \\
\hline & Flight & $\begin{array}{l}\text { Wrong decision to abort } \\
\text { take-off }\end{array}$ & \\
\hline Supervision & Ground Handling & $\begin{array}{l}\text { Poor coordination of } \\
\text { ramp activities }\end{array}$ & $\begin{array}{l}\text { Vehicle crashed } \\
\text { on aircraft } \\
\text { fuselage }\end{array}$ \\
\hline \multirow[t]{3}{*}{$\begin{array}{l}\text { Total (End-user and } \\
\text { Supervision acts } \\
\text { combined) }\end{array}$} & Ground Handling & $\begin{array}{l}\text { Personal object left by } \\
\text { technician in engine air- } \\
\text { intake duct }\end{array}$ & \multirow{3}{*}{$\begin{array}{l}\text { Foreign object } \\
\text { suction from No } \\
2 \text { engine during } \\
\text { taxiing and late } \\
\text { response from } \\
\text { crew, leading to } \\
\text { severe damages } \\
\text { in engine } \\
\text { compressor }\end{array}$} \\
\hline & Ground Handling & $\begin{array}{l}\text { Failure of supervisor to } \\
\text { impose safety standards } \\
\text { during aircraft handling }\end{array}$ & \\
\hline & Flight & $\begin{array}{l}\text { Crew failed to stop } \\
\text { immediately No } 2 \text { engine } \\
\text { upon failure }\end{array}$ & \\
\hline
\end{tabular}

Table 3: Examples of Accidents Attributed to Human Error

\subsection{Dependent and Independent Variables}

The following figures served as independent variables in order to explore correlations with Table 2 variables:

- Per capita cost (see Table 1).

- Ratio of flying hours per employee (AVERAGE TASK LOAD variable). This variable illustrated the average task load per employee for each flying hour.

Taking into account the small sample size, Spearman's correlation tests were performed using PASW 18 Statistics software package. As a first stage, correlation between each independent and dependent variable was calculated. Afterwards, partial correlations were conducted in order to search for the association between each of the two independent variables and the dependent variables, while controlling the other independent variable. The significance level for the tests was set to 0.05 . 


\subsection{Assumptions}

In order to evaluate the potential relationships amongst the variables discussed above, the researcher in consultation with the organization under study applied the following approximations:

- Any fluctuation of employment costs affected proportionally all professional groups of the organization (e.g., percentage of salary reductions or increases were equal for pilots and technicians) and followed the same escalating or declining patterns for all staff annually.

- The flying activity of the aviation organization steered proportionally the task load of all supporting activities (e.g., increase in flying activity brought escalation of maintenance demands). Therefore, the fluctuation of flight hours served as valid estimator of the overall task load variance.

- The annual staff turnover has been less than $2 \%$, hence, the employees' population over time was considered homogeneous.

- Apart from the task load, the various factors affecting the workload (i.e. peer pressure, environmental conditions and mental workload) remained almost constant each year of reference.

Moreover, the study did not account for inflation rates of employment costs because conversion of monetary figures to 2012 or today equivalents, would require a similar conversion of accident rates; correlations between one adjusted variable (employment cost) and a variable not adjusted (accident rates) would not claim validity. However, there have not been published indexes, methods, or underlying theories for converting accident rates to future equivalents. Even if direct accident costs are subjected to inflation, inevitable indirect costs and intangible adverse effects could not be transformed to today values. Accidents occur in a broad organizational 
and social context that varies over time, and they can be "explained" only with reference to specific conditions. Therefore, the researcher assumed a "stable" context only within each year of study.

\section{RESULTS}

Table 4 presents the results of the correlations, with the significant ones underlined. Scatterplots of significant bivariate correlation results are presented in the Appendix.

\begin{tabular}{|c|c|c|c|c|c|}
\hline \multirow{3}{*}{$\begin{array}{l}\text { INDEPENDENT } \\
\text { VARIABLES }\end{array}$} & \multicolumn{5}{|c|}{ DEPENDENT VARIABLES (ACCIDENT RATES ATTRIBUTED TO: ) } \\
\hline & $\begin{array}{c}\text { SUPERVISION } \\
\text { ERROR }\end{array}$ & $\begin{array}{l}\text { MAINTENANCE } \\
\text { STAFF ERROR }\end{array}$ & $\begin{array}{l}\text { FLIGHT } \\
\text { CREW } \\
\text { ERROR }\end{array}$ & $\begin{array}{c}\text { END- } \\
\text { USER } \\
\text { ERROR }\end{array}$ & $\begin{array}{l}\text { TOTAL } \\
\text { HUMAN } \\
\text { ERROR }\end{array}$ \\
\hline & \multicolumn{5}{|c|}{ Bivariate correlations (Spearman's coefficient) } \\
\hline $\begin{array}{l}\text { AVERAGE TASK LOAD } \\
\text { (=ratio of flying hours / } \\
\text { employee) }\end{array}$ & $\begin{array}{l}\rho=0.505 \\
p=0.078\end{array}$ & $\begin{array}{l}\rho=0.549 \\
p=0.052\end{array}$ & $\begin{array}{l}\rho=0.637 \\
p=0.019\end{array}$ & $\begin{array}{l}\rho=0.599 \\
p=0.031\end{array}$ & $\begin{array}{l}\rho=0.588 \\
p=0.035\end{array}$ \\
\hline PER CAPITA COST & $\begin{array}{l}\rho=-0.374 \\
p=0.209\end{array}$ & $\begin{array}{l}\rho=-0.868 \\
p=0.000\end{array}$ & $\begin{array}{l}\rho=-0.780 \\
p=0.002\end{array}$ & $\begin{array}{l}\rho=-0.505 \\
p=0.780\end{array}$ & $\begin{array}{l}\rho=-0.791 \\
p=0.001\end{array}$ \\
\hline & \multicolumn{5}{|c|}{ Partial correlations (Spearman's coefficient) } \\
\hline $\begin{array}{l}\text { AVERAGE TASK } \\
\begin{array}{l}\text { (controlling for } \\
\text { CAPITA COST) }\end{array} \\
\text { PER }\end{array}$ & $\begin{array}{l}\rho=0.393 \\
p=0.103\end{array}$ & $\begin{array}{l}\rho=0.238 \\
p=0.228\end{array}$ & $\begin{array}{l}\rho=0.438 \\
p=0.077\end{array}$ & $\begin{array}{l}\rho=0.457 \\
p=0.068\end{array}$ & $\begin{array}{l}\rho=0.342 \\
p=0.138\end{array}$ \\
\hline $\begin{array}{l}\text { PER CAPITA COST } \\
\text { (controlling for AVERAGE } \\
\text { TASK LOAD) }\end{array}$ & $\begin{array}{l}\rho=-0.152 \\
p=0.318\end{array}$ & $\begin{array}{l}\rho=-0.817 \\
p=0.001\end{array}$ & $\begin{array}{l}\rho=-0.684 \\
p=0.007\end{array}$ & $\begin{array}{l}\rho=-0.286 \\
p=0.184\end{array}$ & $\begin{array}{l}\rho=-0.704 \\
p=0.005\end{array}$ \\
\hline
\end{tabular}

Table 4: Spearman's Correlation Coefficient Results $(N=13)$

The results of Spearman's correlation coefficient application suggested that:

1. The lower the expenditure per employee, the higher:

- The rate of accidents attributed to maintenance staff errors $(\rho=-0.868$, $\mathrm{p}=0.000)$ 
- The rate of accidents attributed to flight crew errors $(\rho=-0.780, p=$ 0.002)

- The rate of accidents attributed to human errors when considering all job functions and roles $(\rho=-0.791, p=0.001)$.

2. The higher the average task load, the higher:

- The rate of accidents attributed to flight crew errors $(\rho=0.637, p=$ $0.019)$

- The rate of accidents attributed to end-users errors concerning all job roles $(\rho=0.599, p=0.031)$

- The rate of accidents attributed to human error when considering all job functions and roles $(\rho=0.588, p=0.035)$.

3. When controlling for the average task load, the lower the average expenditure per employee, the higher:

- The rate of accidents attributed to maintenance staff error $(\rho=-0.817$, $\mathrm{p}=0.001)$

- The rate of accidents attributed to flight crew error $(\rho=-0.684, p=$ 0.007)

- The rate of accidents attributed to human error when considering all job functions and roles $(\rho=-0.704, p=0.005)$.

\section{DISCUSSION}

The results presented in the previous section provide some evidence for the influence of employment costs and task load on accident rates attributed to human error. According to the bivariate correlation results of Table 4: 
- The accident rates attributed to flight crew errors were associated with all independent variables concerned in bivariate correlations. Lower employment costs and higher task load were related to higher accident rates attributed to human errors of the specific professional group.

- The cost per capita influenced significantly and negatively the rates of accidents attributed to maintenance personnel errors. However, it seems that task load did not affect significantly the specific accident rates. This might indicate that the variance of task load concerning maintenance staff was not high enough to cause severe implications on their performance, or this professional group compensated higher task loads by other means (e.g., intensive supervision, increased awareness).

- The rates of accidents attributed to end-user error were positively associated with the average task load.

- The partial correlation results indicated that the lower the per capita cost, the higher the rates of accidents attributed to flight crew, maintenance staff and enduser errors in general, when the task load was controlled.

The results of bivariate and partial correlations are consistent with the literature regarding employee satisfaction and motivation sourcing partially from payment levels and working conditions. One important issue revealed from the results is the significant influence of employment budget on flight crew and maintenance staff errors, as well as on overall human error rates regardless of the task load. On the other side, when the per capita cost was controlled, no significant associations were observed between average task load and accident rates attributed to human errors. The two aforementioned results imply that payment had a greater influence in human performance than task load. 
Interestingly, the current research did not reveal a strong relationship between average employment cost and task load on accidents attributed to supervisory errors. It might be presumed that the accumulated professional experience of this group compensates for the fluctuation of employment budget and task load. Thus, the enduser level demonstrates more vulnerability to working condition changes than the oversight level.

\section{CONCLUSIONS}

The specific research correlated employment budget and task load fluctuations with rates of accidents attributed to human errors of pilots and maintenance personnel directly involved in all phases of aircraft operation, handling and maintenance. The analysis of data from a single aviation organization, the unavailability of data for incidents and Occupational Health and Safety related events, and the lack of data for other professional groups, are limitations for the generalizability of the current study. Furthermore, it must be pointed that since human nature and performance are highly variable (e.g., Dekker, 2002; Hollnagel, 2012, 2014) and dependent on many factors, any attempt to model individual effects on human error, such as the ones explored in this work, would claim only limited validity.

Actually, the fact that payment and task load are not the only factors that influence human error, may shape an opportunity for organizations that encounter financial problems and proceed to budget reductions in order to ensure their sustainability. More specifically, organizations can partially compensate the impact of employment costs decline by strengthening the rest of the factors addressed by Herzberg et al. (1959), such as recognition and advancement. This was reflected in the study of Giamalis and Moschoutas (2013), who concluded that an increase of 
management commitment to transparency and meritocracy could counteract the difficulties that employees faced during the Greek financial crisis.

Taking into account that effects of payment on productivity have been studied in depth, the researcher prompts organizations to explore further the association between employment cost and task load fluctuations and human error. The extension of the current study to include variables that are probably important to search for (e.g., incidents, Occupational Health and Safety events, organizational level and professional groups) would facilitate such initiatives. 


\section{References}

Allsop, R., Eksler, V., Jost, G., \& Popolizio, M. (2009). 2010 on the Horizon, 3rd Road Safety PIN Report. Brussels: ETSC.

Beutell, N. J., \& Wittig-Berman, U. (1999). Predictors of Work-family Conflict and Satisfaction with Family, Job, Career, and Life. Psychological Reports, 85(3Pt1), 893-903.

Broman, M., Edmunds, D., Milner, M., Pentsil, G., \& Young, L. (2014). The Tenuous Relationship between Salary and Satisfaction. Journal of Behavioral Studies in Business, 7, 1-9.

Brubaker, T. L., \& Probst, T. M. (2001). The Effects of Job Insecurity on Employee Safety Outcomes: Cross-sectional and Longitudinal Explorations. Journal of Occupational Health Psychology, 6(2), 139-159.

Dekker, S. (2002). A Field Guide to Human Error Investigations. UK: Ashgate \& Cranfield University Press.

Dekker, S. (2014). Drift Into Failure. UK: Ashgate.

Denny, A. T., Feren, D. B., Locke, E. A., McCaleb, V. M., \& Shaw, K. N. (1980). The Relative Effectiveness of Four Methods of Motivating Employee Performance. In K. D. Duncan, M. M. Gruenberg, \& D. Wallis, Changes in Working Life (pp. 363-388). NY: Wiley.

Diener, E., \& Tay, L. (2011). Needs and Subjective Well-being around the World. Journal of Personality and Social Psychology, 101(2), 354-365.

Eksler, V., Holló, P., \& Zukowska, J. (2010). Road safety performance indicators and their explanatory value: A critical view based on the experience of Central European countries. Safety Science, 48, 1142-1150.

Gawron, V. J. (2008). Human Performance, Workload, and Situational Awareness Measures Handbook. Boca Raton: Taylor \& Francis Group.

Gerhart, B., Minette, K. A., \& Rynes, S. L. (2004). The Importance Of Pay In Employee Motivation: Discrepancies Between What People Say And What They Do. Human Resource Management, 43(4), 381-394.

Giamalis, P., \& Moschoutas, P. (2013). Effects of the Greek Financial Crisis on the Flight and Ground Safety in the Hellenic Air Force. BSc Thesis. Greece: Hellenic Air Force Academy.

Griffin, E. (1996). Hierarchy of Needs by Abraham Maslow, a First Look at Communication Theory. NY: McGraw-Hill.

Gupta, N., Jenkins, D. G., Mitra, A., \& Shaw, J. D. (1998). Are Financial Incentives Related to Performance? A Meta-Analytic Review of Empirical Research. Journal of Applied Psychology, 83, 777-787.

Guzzo, R. A., Jette, R. D., \& Katzell, R. A. (1985). The Effects of Psychologically Based Intervention Programs on Worker Productivity: A Meta-analysis. Personnel Psychology, 38, 275-291. 
Herzberg, F., Mausner, B., \& Snyderman, B. (1959). The Motivation to Work. NY: Wiley.

Hilburn, B., \& Jorna, P. G. (1999). Workload in Air Traffic Control. In P. A. Hancock, \& P. Desmond, Stress, Workload, and Fatigue: Theory, Research, and Practice. USA: Lawrence Erlbaum Associates.

Hollnagel, E. (2012). FRAM - The Functional Resonance Analysis Method. UK: Ashgate.

Hollnagel, E. (2014). Safety-I and Safety-II: The Past and Future of Safety Management. UK: Ashgate.

Huizinga, G. (1970). Maslow's Hierarchy in the Work Situation. Groningen: WoltersNoordhoff.

ICAO. (2004). Human Factors Digest No.16: Cross-Cultural Factors in Aviation Safety. Circular 302-AN-/75. Montreal, CA: International Civil Aviation Organization.

ICAO. (2013). Safety Management Manual. Doc. 9859. Montreal, Canada: International Civil Aviation Organization.

Igalens, J., \& Roussel, P. (1998). A Study of the Relationships between Compensation Package, Work Motivation and Job Satisfaction. Journal of Organizational Behavior, 20, 1003-1025.

Judge, T. A., Piccolo, R. F., Podsakoff, N. P., Rich, B. L., \& Shaw, J. C. (2010). The Relationship between Pay and Job Satisfaction: A Meta-analysis of the Literature. Journal of Vocational Behavior, 77, 157-167.

Judiesch, M. K. (1994). The Effects of Incentive Compensation Systems on Productivity, Individual Differences in Output Variability and Selection Utility. Doctoral dissertation. University of lowa.

Karanikas, N. (2015). An Introduction of Accidents' Classification Based on their Outcome Control. Safety Science, 72, 182-189.

Leveson, N. (2004). A New Accident Model for Engineering Safer Systems. Safety Science, 42(4), 237-270.

Luthans, F., \& Stajkovic, A. D. (1997). A Meta-Analysis of the Effects of Organizational Behavior Modification on Task Performance, 1975-1995. Academy of Management Journal,, 40, 1122-1149.

Maslow, A. H. (1954). Motivation and Personality. NY: Harper and Bros.

Mavor, A. S., McGee, J. P., \& Wickens, C. D. (1997). Flight to the Future: The Human Factors of Air Traffic Control. Washington: National Academy Press.

Pardee, R. L. (1990). Motivation Theories of Maslow, Herzberg, McGregor \& McClelland: A Literature Review of Selected Theories Dealing with Job Satisfaction and Motivation. Retrieved 12 10, 2014, from Education Resources Information Center: http://eric.ed.gov/

Rasmussen, J. (1997). Risk Management in a Dynamic Society: A Modelling Problem. Safety Science, 27, 183-213. 
Stone, G., Gulick, R. K., \& Gabriel, R. F. (1984). Use of Task/Timeline Analysis to Assess Crew Work-load. Longbeach: Douglas Aircraft Company.

Stranks, J. (2006). Health \& Safety Handbook. London: Kogan Page Ltd.

Stranks, J. (2008). Health \& Safety at Work: An Essential Guide for Managers. UK: Kogan Page Ltd.

Yankelovich, D. (1981). Stepping off Maslow's Escalator. In D. Yankelovich, New Rules: Searching for Self-Fulfilment in a World Turned Upside Down (pp. 231-240). NY: Random House. 
APPENDIX

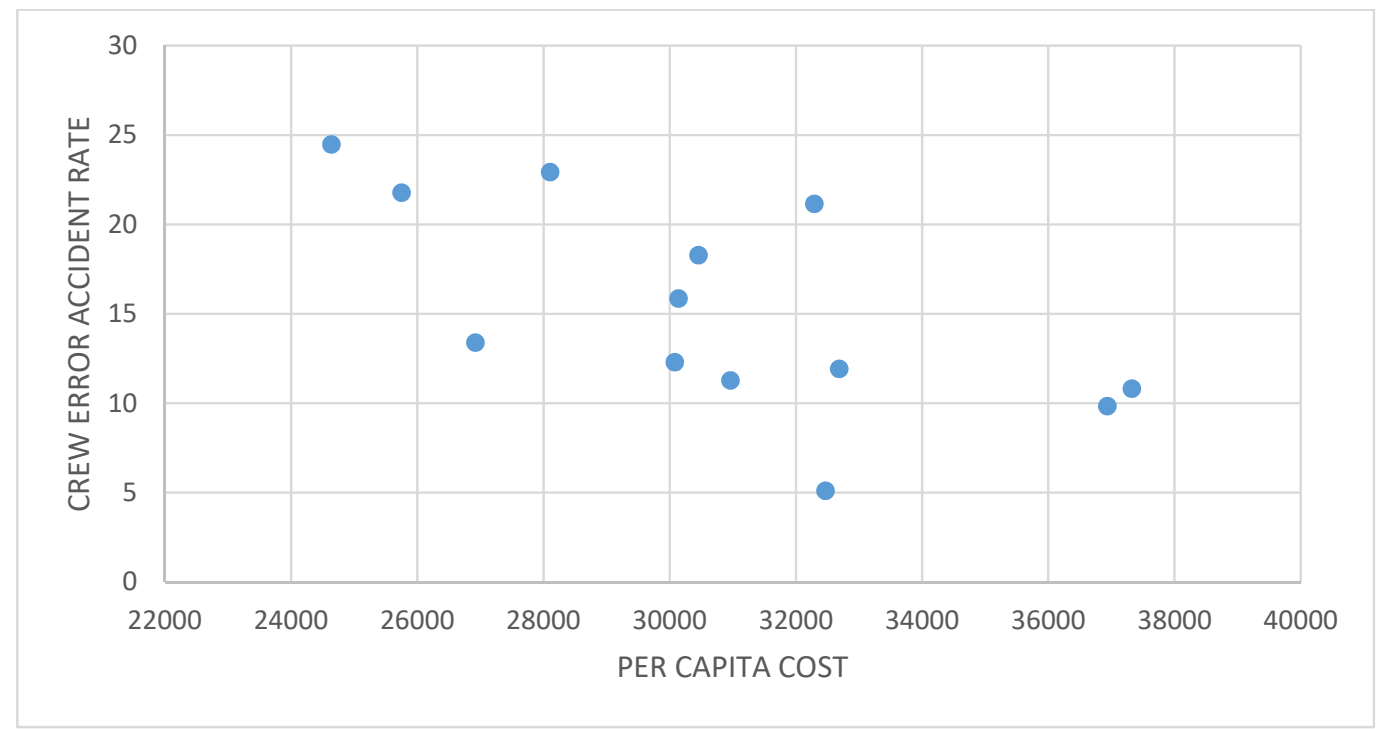

Figure 1: Scatterplot of per capita cost VS crew error accident rate (per 100,000

flying hours) 


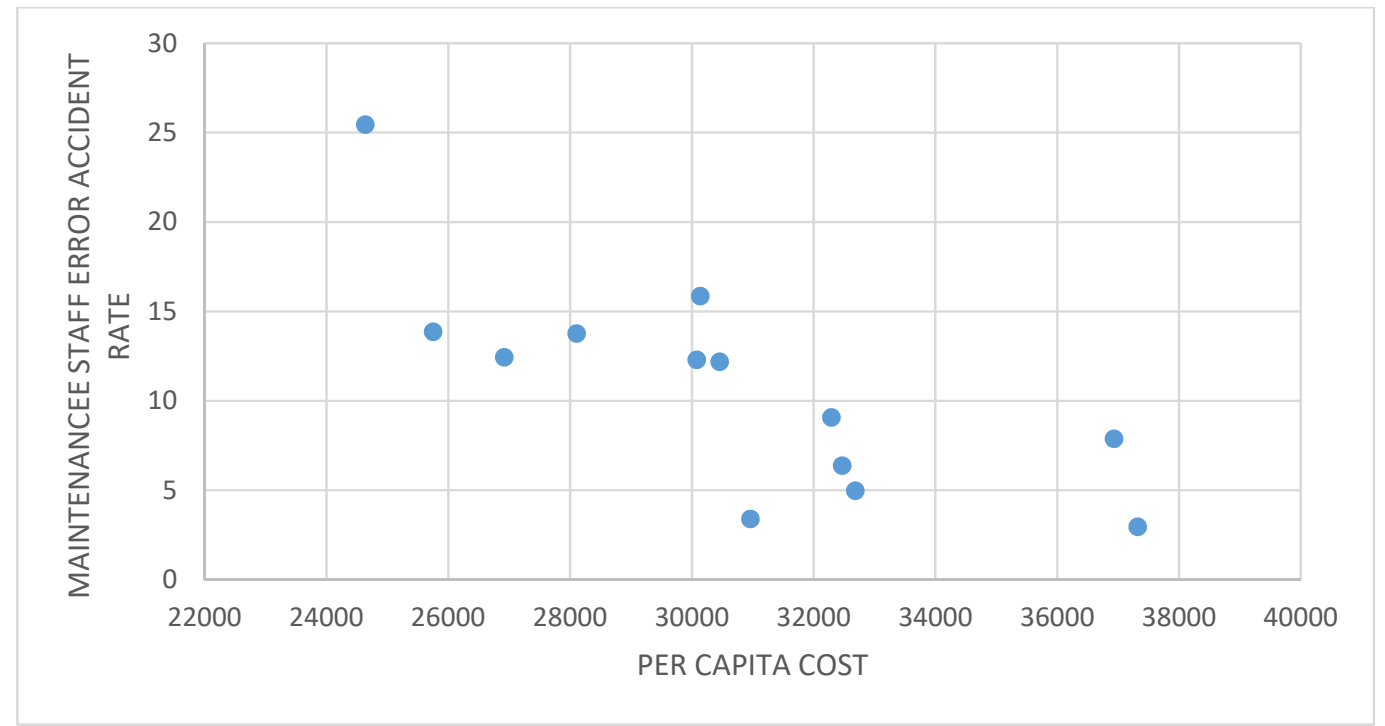

Figure 2: Scatterplot of per capita cost VS maintenance staff error accident rate (per $\underline{100,000 \text { flying hours) }}$ 


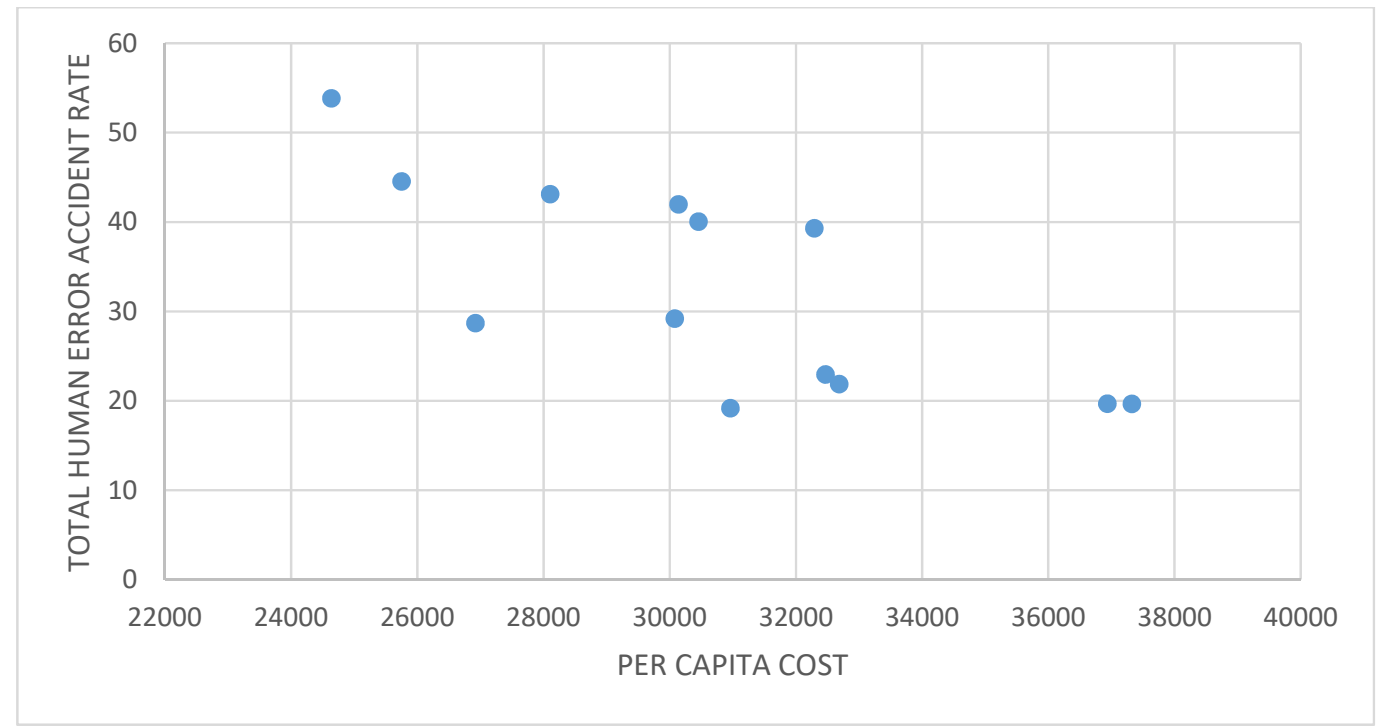

Figure 3: Scatterplot of per capita cost VS total human error accident rate (per $\underline{100,000 \text { flying hours) }}$ 


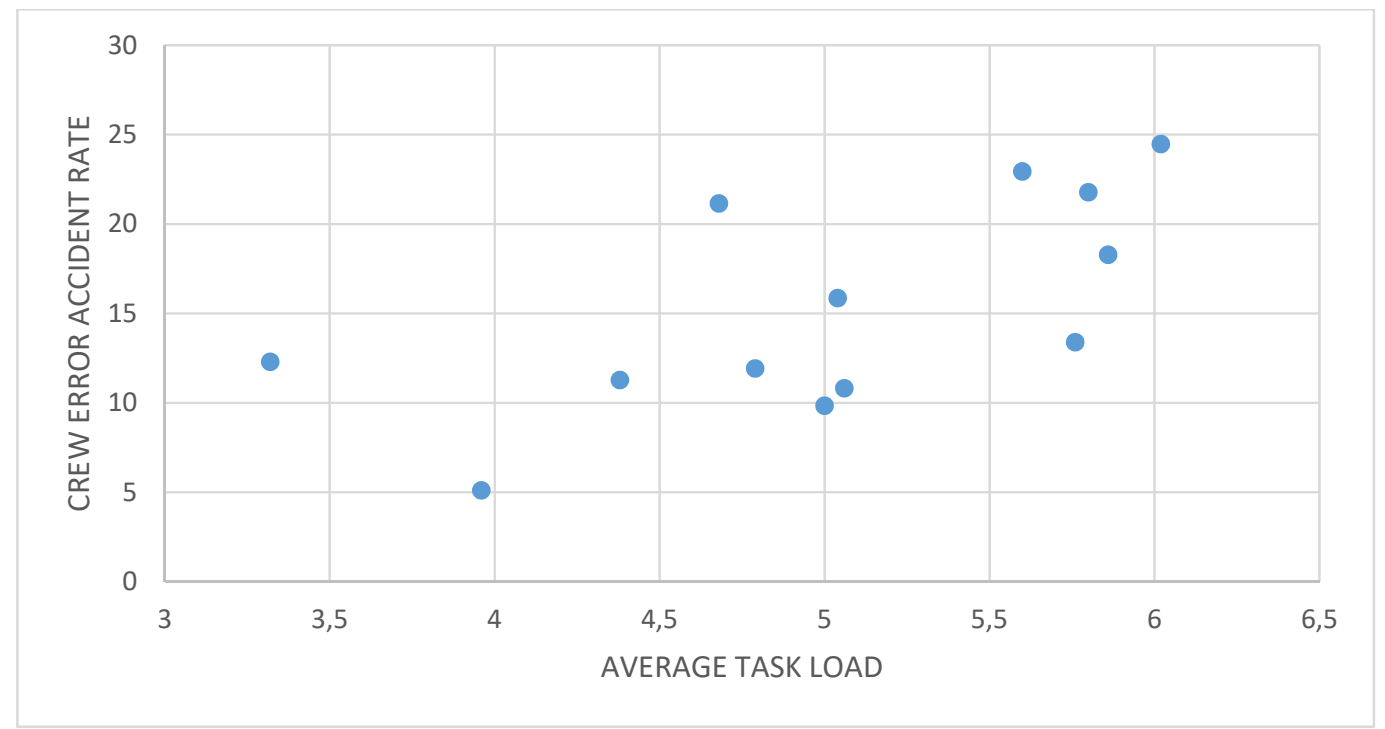

Figure 4: Scatterplot of average task load VS crew error accident rate (per 100,000

flying hours) 


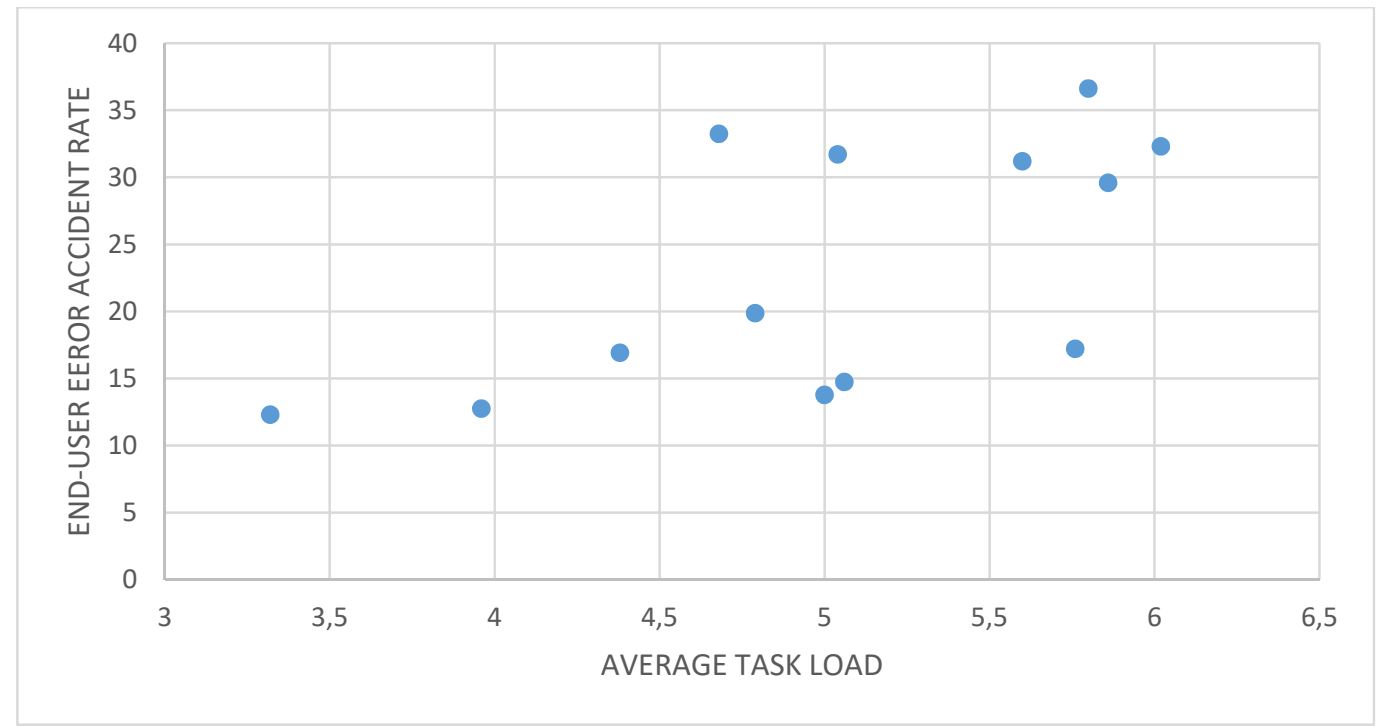

Figure 5: Scatterplot of average task load VS end-user error accident rate (per $\underline{100,000 \text { flying hours) }}$ 


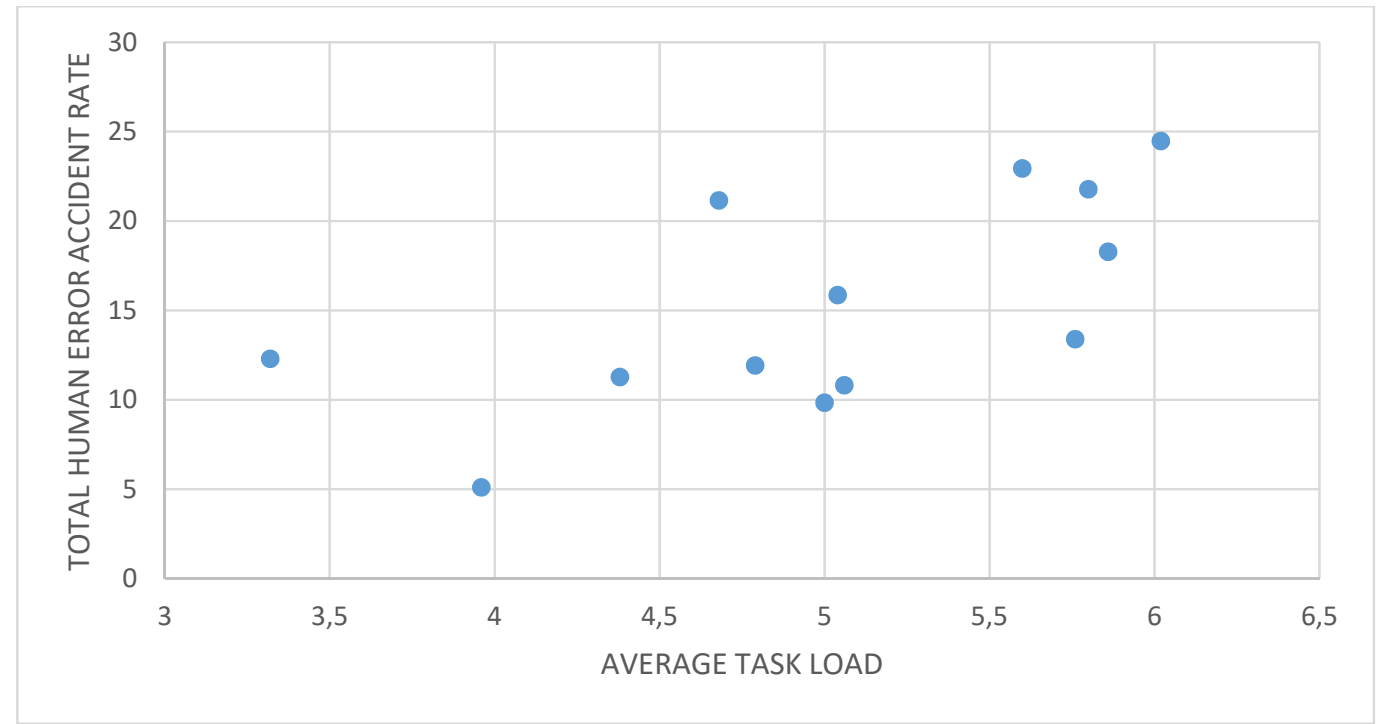

Figure 6: Scatterplot of average task load VS total human error accident rate (per 100,000 flying hours) 